\title{
Structural Equation Modelling (SEM) Analysis of the Influence of Religious Films on Pro-social Behaviour of Audience
}

\author{
Rosmawati Mohamad Rasit ${ }^{1}$ \\ ${ }^{1}$ Department of Da'wah \& Leadership Studies, Faculty of Islamic Studies, Universiti Kebangsaan Malaysia, \\ Bangi, Selangor, Malaysia \\ Correspondence: Rosmawati Mohamad Rasit, Department of Da'wah \& Leadership Studies, Faculty of Islamic \\ Studies, Universiti Kebangsaan Malaysia, Bangi, 45600, Selangor, Malaysia. Tel: 60-38-921-5359. E-mail: \\ rosmawati@ukm.edu.my
}

Received: November 9, 2014 Accepted: April 9, 2015 Online Published: June 5, 2015

doi:10.5539/ass.v11n18p42

URL: http://dx.doi.org/10.5539/ass.v11n18p42

\begin{abstract}
This study discusses the effect of religious films as a factor that influences the form of pro-social behaviour. A young audience comprised of 1028 respondents were selected from a public institution of higher learning in Malaysia by stratified random sampling. This study uses a cross sectional survey through the distribution of questionnaires as instruments. Data collected were analysed based on the hypothesis model developed and tested by structural equation model (SEM) using AMOS 21.0. The findings of the study show that pro-social behaviour corrrelates with the exposure of films, watching of the religious films and the message in the pro-social films. Thus, it can be concluded that religious films influence the development of pro-social behaviour among youthful audience.
\end{abstract}

Keywords: Structural Equation Model (SEM), influence, film exposure, religious films, pro-social behaviour

\section{Introduction}

Films are considered as audio-visual tools to spread messages. Some countries use films to disseminate their political ideology propaganda. Some even use films to preserve their cultural and historical heritage and to elevate the social system of a race or even religious interest (Benyahia, 2008; Harbord, 2002; Flesher \& Torry 1998). According to Muhammad Hatta (2006), films are not merely silver halide which acts as an image recorder but also record the reality of life. Films, besides being entertainment tools, (Zulkiple, 2003) are also educational media to stimulate learning among youth. According to Wimmer and Dominick (2009), the study on the influence of media on pro-social content is still a new field of study which proves that anti-social action should involve more positive behaviour. Nevertheless, Wimmer and Dominick (2009) also said that the interest to study the influence of media on pro-social behaviour had declined in the 1980s and even in the late 2000s, the number studies on this subject was still at a low level.

Therefore, the religious aspect in films should be expanded and more clearly discussed. World religions such as Islam and Christianity touch on many religious issues in films such as The Message (1977) and The Ten Commandments $(1956,2006)$. Bollywood films also identify the religious issue with the daily life of Hindu society. This can be perceived in scenes which directly feature shots of temples and praying, whether in classical or modern films such as Mother India (1957) and Kuch Kuch Hota Hai (1998). Hence, the issue arises as to how much religious element may affect the audience. Many questions arise about whether the audience are able to understand and practise what they watch in daily life. People in the community need films that portray a religious-based lifestyle and culture. This is because films should not be just some empty sketches on canvas devoid of values and religious content.

\subsection{Films and Audience}

Md Salleh et al. (2009) found that in terms of film choices, boys like to choose action, animation and comedy films. Many of them choose to watch films through television and DVD/VCD. On the other hand, Madsen (1973) in discussing films as a propaganda tool explained that films are able to audio-visually manipulate the thoughts and beliefs of the audience. According to Asiah (2009), Malay films are included as third world cinema which 
are directly geared to function as agents of change. The film industry in Malaysia links films with social culture in the community, for example, the films Hang Jebat (1961), Puteri (1987) and Wayang (2008).

There are numerous research which discuss audience in media and communication. Audience becomes the most important element in mass media that contributes to the success of a media product. The change in audience behaviour from passive to active makes the audience a selective entity with power to choose its own media (Garamone, 1984; Jensen \& Rosengren, 1990; Clifford, 2005; Mastura, 2005). Background, gender and ethnicity are the main factors that contribute to the differences in how an audience understands and interprets messages in media text which ultimately influences the pattern and effects of their watching (McQuail, 2000).

Zalila (2007) discussed the influence of films as the main platform for teenagers or youth to understand themselves although some require re-structuring in terms of content, theme, consistent usage of Malay language, etiquette and values, culture and so on. Films are the most influencial communication media in highlighting moral and good messages (Suhaina, 2006; Dusuki, 2000). Smets (2012) in his research on the film The Message (2012) showed that a religious message such an Islamic lifestyle could be conveyed via films to new generations. Messages like unity, equitability, purity of soul and morals in films may be the source of religious inspiration and guidance in the community (Smets, 2012).

Therefore, films also play the role of highlighting the value of responsibility guided by the main objective concerning issues in question in a film, as well as the solutions to problems so that the community may gain some good and benefit from their watching (Hasliza, 2009). Naim (2011) discusses the role of films as a communication media in spreading messages in teaching, persuasion, clarification and da'awah (preaching). Good film producers are able to master the language of films and use it in da'awah (preaching), giving advisory messages and calling to goodness (Naim, 2011). Thus, Asiah (2003) argued that it is very important for films producer to review issues related to the background of the film content in order to maintain and foster the values of the Malaysian society. Asiah (2003) also discussed the factors that influence both the good and bad values and messages contained in local films and the perception of the public towards them.

\subsection{Pro-social Behaviour}

Among past studies was a research conducted on pro-social behaviour correlated with the role of media (Strasburger et al., 2009; Wilson, 2008; Dumova, 2006; Yates, 1999). However, that study used children and teenagers (Strasburger et al., 2009; Gentile et al., 2009; Wilson, 2008; Ostrov et al., 2006; Mueller \& Donnerstein, 1981) as their samples in studying pro-social behaviour. Strasburger et al. (2009) said that researchers who studied pro-social learning through media placed the assumption that media characters like to portray values such as kindness, mutual cooperation, responsibility and selflessness as decent examples for children to follow.

Muller \& Donnerstein (1981) did two experiments about pro-social behaviour by showing films that contain arousal elements using the excitation transfer model. Their study on male college students was seen from two perspectives, positive and neutral behaviour. The samples were shown both erotic and non-erotic (controlled) films. The findings of the study showed that the arousal films enhanced punishing behaviour among the samples. Whereas, for the controlled group, the sample showed more positive behaviour (Muller \& Donnerstein, 1981). Gentile et al. (2009) in their study showed positive pro-social behaviour with the exposure of pro-social video games.

\subsection{Audience Reception Theory}

The media reception study emphasized on the study of audience as interpretive communities. This concept explains the role of audience as reader in translating media text. Media text need to be read through audience perception which will shape different meanings and forms of acceptance (McQuail, 2000). Hall (1993) introduced the Audience Reception Theory that explains how audience accepts and reads messages from the media. According to Hall (1993) again, audience recorded different meanings based on their perspectives and needs from what they saw through the media even though at times they shared the same experience.

Therefore, the audience of films are the important decoder in the process of sending mass communication information in the films shown. Many in the audience nowadays, are active in giving meaning, interpreting and evaluating films according to their perspectives. This builds up a new paradigm about audience and films and the reality of life that they obtain from the films. The Reception Theory shapes audience perception through their evaluation of films that they watched. This study is basically using this Audience Reception Theory to look at the relationship betweeb audience and films producers in giving and receiving messages together with the values applied in films. 


\section{Methodology}

\subsection{Research Paradigm Perspective}

Paradigm is a basic assumption, way of thinking and believing that form the basis of impleenting a research and is also known as 'philosophical worldview' (Creswell, 2008; Greene \& Caracelli, 2003; Johnson \& Onwuegbuzie, 2004; Morgan, 2007). Researchers must always understand the basis of a paradigm to explain the chosen research approach whether it is quantitative or qualitative or even mixed methods as Creswell (2009) and Morgan (2007) have stated how a worldview shapes the research approach chosen by researchers. This study refers to the quantitative paradigm research that is moving towards post-positivism (Morgan, 2007; Creswell, 2008; Johnson \& Onwuegbuzie, 2004; Miller, 2005; Gray, 2009). Positivism which was inititated by Aristotle, Francis Bacon, August Comte and Immauel Kant is for the purpose of testing a theory through measurement in research. Positivism assumes that social phenomenon may be determined by the cause and effect relationship and axiology (study of values) approach. However, after the Second World War, the post-positivism stream had started to expand replacing positivism thinking. Through this post-positivism, researchers strive to conduct research through testing of theory, whether theory is supported or refuted. The knowledge developed through the lens of post-positivism is based on measurement of objective reality as proof of social behaviour (Morgan, 2007; Livesey, 2006; Creswell, 2009).

\subsection{Research Design}

This research uses a quantitative approach through cross sectional survey. It is also quantitative based on objective measurement of variables. Measurement of the quantitative data explains the phenomenon and measurement of the elements involved in the phenomenon discusses the theory in more detail. Quantitative data are analysed by using statistical analysis generalised to the population with the same charactistics as the sample (Noraini, 2010; Creswell, 2008 \& 2009; Gray, 2009).

\subsection{Research Sampling Procedure}

Stratified random sampling was used in this study. Five public universities (UPM, UIA, UM, UKM and UiTM) with six programmes which offered media, communication and films were chosen as the location to choose the samples randomly. There were 1028 respondents chosen as samples for this study out of an overall population 3324. The size of the research sample accords with the suggestions of Cohen et al. (2007) using a $95 \%$ level of confidence with 5\% confidence intervals. Chua (2006) and Neuman (2006) explained that the quality of research depends on the samples. The findings obtained from the correct value of research samples through probability sampling will be generalised to the whole population. Good samples are samples that may represent variables from the population (Noraini, 2010; Gray, 2009). Hence, this study took into account samples that may be generalised to the whole population.

\subsection{Research Instruments}

The set of questionnaire in this study is a combination of the instrument developed by the researcher and adapted instrument developed by Penner et al. (1995), Prosocial Personality Battery (PSB), for social behaviour variable.

\subsection{Data Collection and Data Analysis}

Data were gathered through the distribution of questionnaires and were analysed based on the hypothesis model developed and tested through the Structural Equation Model (SEM) using AMOS 21.0.

\section{Findings and Discussion}

The results of the SEM showed that the regression model suggested by researcher is suitable where all the three variables; exposure to films, watching films and message in the films are significant predictor variables for the pro-social variable (exposure to films: $\beta=.110$, C.R. $=3.098, \rho<.05$; watching religious films: $\beta=.144$, C.R. $=$ $3.372, \rho<.05$; message in the films: $\beta=.383$, C.R. $=8.200, \rho<.05)($ Table 1$)$.

Table 1. Results for the hypothesis testing standardized regression weight

\begin{tabular}{lcccc}
\hline Variables & Regression Weight & S.E & C.R & $\rho$ \\
\hline Pro-social Behaviour $\leftarrow$ exposure to films & 0.110 & 0.19 & 3.098 & .002 \\
Pro-social Behaviour $\longleftarrow$ watching religious films & 0.144 & 0.27 & 3.372 & .000 \\
Pro-social Behaviour $\longleftarrow$ message in the films & 0.383 & 0.32 & 8.200 & .000 \\
\hline
\end{tabular}


The findings of this study also show that the influence of films has an effect on pro-social behaviour. Even though the study on the effect of films was inclined towards the negative effect, that did not stop Ostrov et al. (2006) from conducting a study to identify the relationship between films and pro-social behaviour. The longitudinal study of Ostrov et al. (2006) was looking at pre-kindergarten children's behaviour (aggressive and pro-social) and its relationship with exposure of media such as TV, films and videos. The findings showed that both media exposures (positive towards learning and positive towards violence) have an effect on the respondents. These effects indeed have a significant relationship with the increasing problem of aggressive behaviour. This shows that films also play a role in developing positive behaviour.

Similarly with the watching of religious films variable where it has a significant relationship with pro-social behaviour and this shows the role of religion in the movie industry. This is similar to what Hardy \& Carlo (2005) argued that religiosity has a positive significant relationship with pro-social predictor variable like kindness, obedience and altruistic values. Thus, when audience is often exposed to religious values in films, it will have an effect on their behaviour. Research on correlation between religion and films is not strange and many researchers have done them such as Deacy (2009), Lindvall (2004), Matties (1998) and Flesher \& Torry (1998). These film researchers and academicians researched on films from the Christian perspective. This study confirms with what has been discussed by Smets (2012) that the watching of Islamic concept films exposes the audience to the reality and information about Islam. It also enables the audience to visualise the context of life and adherence to Islam. When audience is exposed to the films that are inclined towards pro-social values, they may develop the same perception and accept the message which will translated into their behaviour.

Message in the films also show some positive significant relationship with pro-social behaviour. The findings of this study shows that goodness messages in films help to influence the behaviour of the audience to be more positive. Films may deliver messages which change the audience's values, attitude and behaviour (Abdullah et al., 2009; Mohd Arif et al., 2007). This is similar to what Zalila (2007) said that films could be the main platform for young ones (youth) to know about themselves and need to be restructured in terms of content, theme, consistent use of Malay language, courtesy and value. Films are the most influential communication media in highlighting moral elements and good messages (Suhaina, 2006; Dusuki, 2000).

Besides that, the correlation coefficient among the three exo-genius pairs of variables show that the correlation among the watching of the religious films and messages in the films are moderately strong (watching religious films - message in the films: $r=.575$, C.R. $=13.030, \rho<.05$ ), whereas the other two correlations are weak (message in the films - exposure to films: $r=.243$, C.R. $=6.727, \rho<.05$; watching religious films - exposure to films: $\mathrm{r}=.160$, C.R. $=4.515, \rho<.05$ ). These show that all the three variables are influencing one and another (Table 2). This study has also strengthened the Audience Reception Theory which proves the existence of the relationship among the audience itself as Hall (1980) discussed.

Table 2. Coeeficient correlation between exogenius variables

\begin{tabular}{lllll}
\hline Variables & Correlation & S.E & C.R & $\rho$ \\
\hline Message in the films $\leftrightarrow$ Watching religious films & 0.575 & 0.014 & 13.030 & .000 \\
Exposure to films $\leftrightarrow$ Message in the films & 0.243 & 0.014 & 6.727 & .000 \\
Exposure to films $\leftrightarrow$ Watching religious films & 0.160 & 0.015 & 4.515 & .000 \\
\hline
\end{tabular}

Overall, the analysis of the SEM shows that the values of variance in the endo-genius variable Pro-social Behaviour anticipated by the three variables is .269 . This shows that 26.9 percent of the variance in the pro-social behaviour is anticipated by the three exo-genius variables (watching religious films, message in the films and exposure to films). This means that 73.1 percent variance in the variable pro-social behaviour cannot be anticipated by the regression model. This variance may be due to unidentified external factors in this study (Figure 1). Based on this study, there are other factors not included in this study that may act as main predictors which influence the development of pro-social behaviour of respondents. Therefore, it cannot be denied that factors like unity of family and peer acceptance may influence results (Wentzel \& McNamara, 1999).

Therefore, based on the findings, this study has proven that religious films have the ability to contribute to influence on pro-social behaviour. Even though the percentage of the contributions is low, only 26.9, the influential contribution of films is undeniable. The study shows that films have the effect of changing behaviour. 


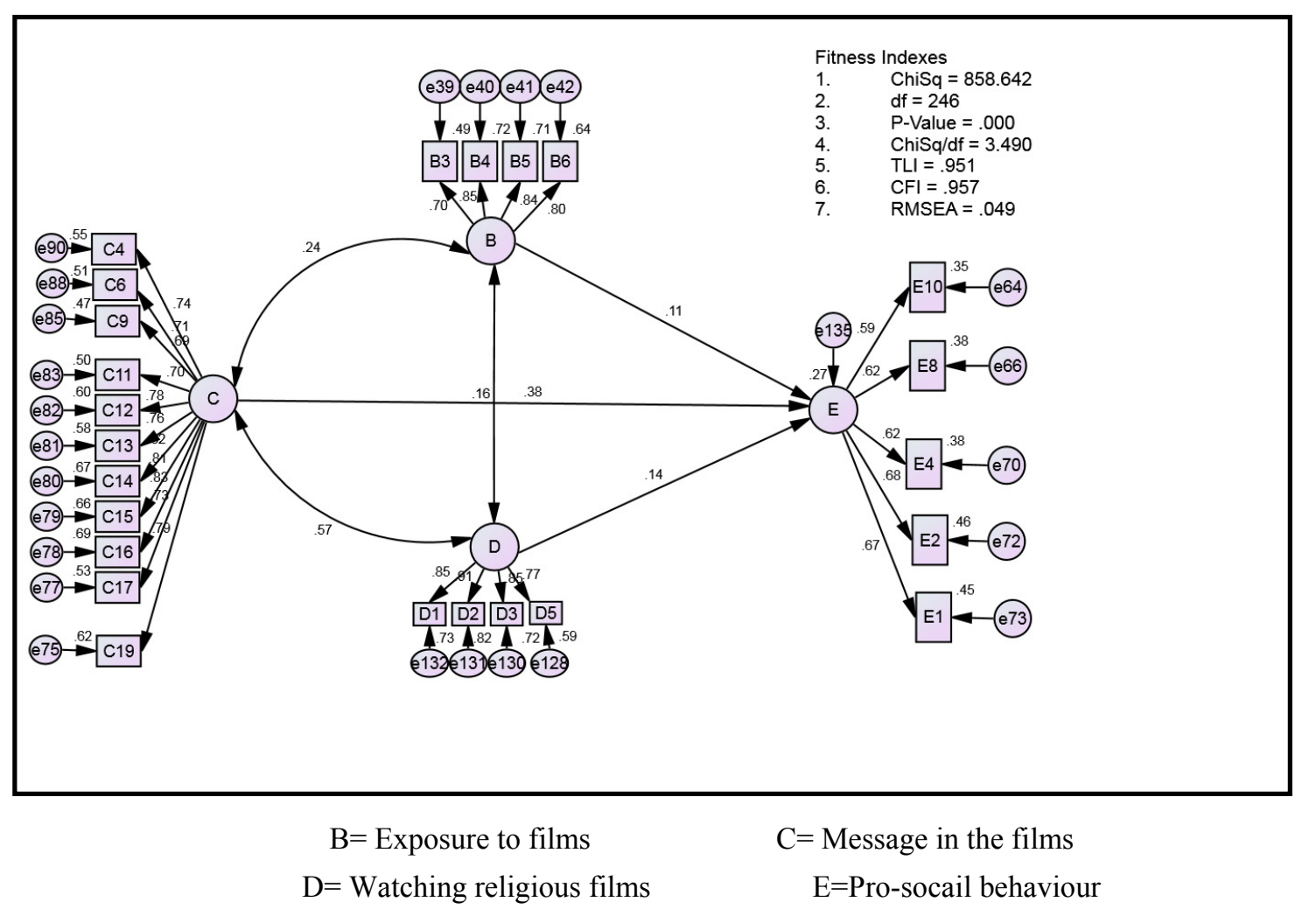

Figure 1. Regression model that shows the findings of analysis

\section{Conclusion}

The influence and effect of films on the audience portray the significant role of films that can cause changes in behaviour. Hence, in addition to research done on the negative effects of films, this study has proven that films play a role as medium to convey messages for positive effect. Positive behaviour such as pro-social behaviour is seen as behaviour that can be conveyed and translated through films. The development of a more harmonious community that has all the pro-social values like helping each other, empathy and caring may be sown when these films are made to promote pro-social values.

This study has also proven that there is a significant relationship between the exposure to films, watching religious films and message in films with pro-social behaviour. This means that audience should be exposed to the films that carry good values to develop positive behaviour. Thus, these values could be uplifted directly through religious films that convey them to the community. Although the contribution of these films is only 27 percent, the community is still in need of these religious films so that more good messages could be delivered to them. The more audience is exposed to the religious films, the higher the pro-social behaviour of the people. The development of pro-social values is important in shaping young generations to come back to the meaning of life in a community through the practising of values like helping each other and caring for one another in Islam.

\section{References}

Yusof, A., Rahim, R. A. Abd., \& Kadir, N. A. A. (2009). Islamic movies as communication and technologies products: an analysis of the concept and attitude of higher learning institution in Malaysia. Paper Presented at International Seminar on Islamic Education on Communication and Technologies, 19-20 December, Banda Acheh Indonesia.

Sarji, A. (2003). The film and its impact on society in ensuring the preservation and enrichment values of malaysian society. Malaysian Journal of Communication, 19, 1-21.

Sarji, A. (2009). The development of Malaysian film industry in context of Islam Hadhari approach. In M. S. Hasim, \& Z. Abd. Ghani (Eds.), Communication In Malaysia A Preliminary Research on Islam Hadhari Approach (pp. 193-218). Bangi: Institut Islam Hadhari, Universiti Kebangsaan Malaysia.

Benyahia, S., Gaffney, F., \& White, J. (2008). As film studies the essential introduction (Ke-2 ed.). London: 
Routledge Taylor \& Francis Group.

Piaw, C. Y. (2006). Research Methodology Book 1. Kuala Lumpur: McGrawHill Education (Malaysia).

Clifford, R. (2005). Engaging the audience: The social imaginary of the novela. Television New Media, 6, 360-369.

Creswell, J. W. (2008). Educational research planning, conducting and evaluating quantitative and qualitative research (Ed. Ketiga). New Jersey: Pearson Education, Upper Saddle River.

Creswell, J. W. (2009). Research design: qualitative, quantitative and mixed-methods approaches (Ke-3 ed.). USA: Thousands Oaks Sage.

Deacy, C. (2009). Using film in theology and religious studies. Religion Compass, 3(5), 909-919. http://dx.doi.org/10.1111/j.1749-8171.2009.00177.x

Dumova, T. (2006). Prosocial learning. International Journal of Learning, 2(9), 183-194. Retrieved from http://www.learning-journal.com

Ahmad, D. (2000). The challenge of da'wah in utilizing drama industry. In F. Md. Sham, S. Ibrahim, \& I. Endot (Eds.), Dakwah and Social Change (pp. 94-103). Kuala Lumpur: Utusan Publications \& Distributors Sdn. Bhd.

Flesher, V. M., Paul, \& Torry, R. (1998). Teaching religion and film. The Journal of Religion and Film, 2(3). Retrieved from http://www.unomaha.edu/jrf/Fleshart.htm

Garramone, G. M. (1984). Audience motivation effects: More evidence. Communication Research, 11, 79-96.

Gentile, D. A., Anderson, C. A., Yukawa, S., Ihori, N., Saleem, M., Ming, L. K., ... Sakamoto, A. (2009). The effects of prosocial video games on prosocial behaviors: International evidence from correlational, longitudinal and experimental studies. Personality and Social Psychology Bulletin, 35(6), 752-763. http://dx.doi.org/10.1177/0146167209333045

Gray, D. E. (2009). Doing research in the real world (Ke-2 ed.). London: Sage Publications Ltd.

Greene, J. C., \& Caracelli, V. J. (2003). Making paradigmatic sense of mixed methods practice. In A. Tashakkori, \& C. Teddlie (Eds.), Handbook of Mixed Methods in Social \& Behavioral Research (pp. 91-134). California: Sage Publications.

Hall, S. (1993). Encoding, Decoding. In S. During (Ed.), The Cultural Studies Reader. London: Routledge.

Harbord, J. (2002). Film Cultures. London: Sage Publications.

Hardy, S. A., \& Carlo, G. (2005). Religiosity and prosocial behaviours in adolescence: the mediating role of prosocial values. Journal of Moral Education, 34(2), 231-249. http://dx.doi.org/10.1080/03057240500127 210

Hassan, H. (2009). Local Movies Need Values for Social Responsibility. Retrieved from http://www.bharian.com.my/

Johnson, R. B., \& Onwuegbuzie, A. J. (2004). Mixed methods research: a research paradigm whose time has come. Educational Researcher, 33(7), 14-26.

Jensen, K. B., \& Rosengren, K. E. (1990). European Journal of Communication, 5, 207-238.

Lindvall, T. (2004). Religion and film. Communication Research Trends, 23(4), 1-35. Retrieved from http://cscc.scu.edu/trends/v23/v23_4.pdf

Livesey, C. (2006). As sociology revision sociological methods. Retrieved from http://www.sociology.org.uk

Madsen, R. P. (1973). The Impact of Film. New York: Macmillan Publishing co., Inc.

Matties, G. (1998). Religion and Film: Capturing the Imagination. The Journal of Religion and Film, 2(3). Retrieved from http://www.unomaha.edu/jrf/imagine.htm

Muhammad, M. (2005). Audience: Concept, theory, uses and gratifications. Malaysia Screen Journal, (2).

McQuail, D. (2000). Audience Analysis. London: Sage Publications.

Hassan, Md. S., Osman, M. N., \& Azarian, Z. S. (2009). Effects of watching violence movies on the attitudes concerning aggression among middle schoolboys (13-17 years old) at international schools in Kuala Lumpur. European Journal of Scientific Research, 38(1), 141-156.

Miller, K. (2005). Communication theories perspective, processes and contexts (Ke-2 ed.). New York: 
McGraw-Hill Companies. Inc.

Ismail, M. A., Rahman, M. J. A., Lubis, M. A., \& Mahmud, R. (2007). Islamic Education Through The Use of Film in Teaching and Learning. Proceedings of Islamic Education Discourse, 2007. Web. 10 June 2010.

Morgan, D. L. (2007). Paradigms lost and pragmatism regained: methodological implications of combining qualitative and quantitative methods. Journal of Mixed Methods Research, 1(1), 48-76. http://dx.doi.org/10.1177/2345678906292462

Muller, C. W., \& Donnerstein, E. (1981). Film-facilitated arousal and prosocial behavior. Journal of Experimental Social Psychology, 17, 31-41.

Tabut, M. H. M. (2003). Local filmmakers: P. Ramlee and Rahim Razali. In R. Mohamed (Ed.), Cinema and Viewing in Malaysia (pp. 45-73). Penang: Universiti Sains Malaysia.

Ahmad, N. (2011). Islamic Film A Discussion. Shah Alam: Uni-N Production Sdn. Bhd.

Idris, N. (2010). Reseacrh in Education. Malaysia: McGraw-Hill.

Ostrov, J. M., Gentile, D. A., \& Crick, N. R. (2006). Media exposure, aggression and prosocial behaviour during early childhood: a longitudinal study. Social Development, 15, 612-627.

Penner, L. A., Fritzsche, B. A., Craiger, J. P., \& Freifeld, T. R. (1995). Measuring the prosocial personality. In J. Butcher dan C. D. Spielberger (Ed.), Advances in Personality Assessment, 10, 147-164. Hillsdale, New Jersey: Erlbaum.

Strasburger, V. C., Wilson, B. J., \& Jordan, A. B. (2009). Prosocial effects of media. In Children, Adolescents and the Media (2nd ed., pp. 117-144). Thousand Oaks, CA: Sage Publications, Inc.

Smets, K. (2012). Connecting Islam and film culture: the reception of The Message (Ar-Risalah) among the Moroccan diaspora. Journal of Audience \& Reception Studies, 9(1), 68-94. Retrieved from http://www.academia.edu/1617513/Connecting_Islam_and_film_culture_The_reception_of_The_Message_ Ar_Risalah_among_the_Moroccan_diaspora

Ludin, S. H. M. (2006). The Effectiveness of Da'wah Through Music And Art: A Survey of The Psychological Perspective. Proceedings of the Regional Seminar Da'wah and Islamic Art, 35-47.

Wentzel, K. R. dan M., \& Carolyn, C. (1999). Interpersonal relationship, emotional distress and prosocial behavior in middle school. The Journal of Early Adolescence, 19(1), 114-125.http://dx.doi.org/10.1177/ 02724316990190010006

Wilson, B. J. (2008). Media and children's aggression, fear and altruism. Journal Children and Electronic Media, $18(1), 87-118$.

Wimmer, R. D., \& Dominick, J. R. (2009). Research in media effects. Retrieved from http://www.rogerwimmer. com/mmr9e/mediaeffectsmmR9e.pdf

Yates, B. L. (1999). Modeling strategies for prosocial television: a review. Paper presented at Open Paper Competition AEJMC Southeast Colloqium, 4-6 March Lexington, Kentucky.

Zalila, I. (2007, December 5). Film and Malaysian Youth. Retrived from http://www.yadim.com.my/

Zulkiple, A. G. (2003). Islam, Communication and Information Technology. Kuala Lumpur: Utusan Publications \& Distributors Sdn. Bhd.

\section{Copyrights}

Copyright for this article is retained by the author(s), with first publication rights granted to the journal.

This is an open-access article distributed under the terms and conditions of the Creative Commons Attribution license (http://creativecommons.org/licenses/by/3.0/). 